\title{
The Enlightenment of Western Unemployment Theory on the Hard Employment of College Graduates
}

\author{
Xiaoqin $\mathrm{Wu}$ \\ Shandong Technology and Business University \\ Yantai, Shandong, 264005
}

\begin{abstract}
The major unemployment theories in the West include the voluntary unemployment theory of the classical school, the involuntary unemployment theory of the Keynesian school, and the unemployment theory of the neoclassical synthes is school. At present, our college students are hard to find jobs, mainly due to the ineffective bridge between the labor market and the education system, as well as social welfare and urban-rural differences. Currently, the difficult employment for university students in the short-term is aligned with China's economic development phase. According to Western unemployment theories, some inspirations for helping university graduates' employment are obtained: setting majors and courses reasonably, increasing rural investment, attaching importance to the role of the government in labor and employment and the significance of human capital investment. We hope that with the supporting materials in this paper, students can apply suitable professional courses according to reasonable time arrangements during their college life, and make different types of career planning in different grades. We will respond actively to the Party Central Committee's call to alleviate poverty targeted by making the rural investment the key task, while intensifying the government's macro-control to link the employment of students with local employment. We will set up an employment consulting office, in order to increase steadily the employment rate by assorting positions and majors properly, and planning scientifically employment positions.
\end{abstract}

Keywords-western unemployment theory; university students' employment; structural unemployment; human capital

\section{OVERVIEW OF WESTERN UNEMPLOYMENT THEORY}

Western economists have paid attention to unemployment for a long time, and have also conducted long-term research and exploration on the theory of unemployment. The following theoretical viewpoints have been formed:

\section{A. Complete marketregulation}

The theory of voluntary unemployment of the classical school is mainly Keynes' previous theory of unemployment, based on the premise of the private ownership of the means of production and the assumption of complete free competition. From the perspective of classical economists, in the perfect competition, if wage can fluctuate in line with changes in labor supply and demand, all available labor resources can be used for production and full employment can be achieved through the spontaneous adjustment of the market price mechanism.
They also pursued a policy of laissez-faire in the labor market and proposed countermeasures to solve the unemployment problem. They focused on eliminating the rigidity of currency and argued that if the money supply and price levels are not changed, they can reduce real wages by lowering money wages, thus increasing employment [1].

\section{B. State intervention}

In 1936, Keynes published a book "The General Theory of Employment, Interest, and Money", proposing a different employment theory from that of traditional western economics. In his opinion, depending solely on the spontaneous force of the market, we cannot achieve a balance between supply and demand, and form the "effective demand" sufficient to eliminate "involuntary unemployment" and achieve full employment. Keynes believes that the root cause of the "involuntary unemployment" is the shortage of effective demand and the other three basic rules also demonstrate the possibility of long-term "involuntary unemployment", namely "decreasing consumption trends" resulting in inadequate consumption; "decreasing marginal efficiency of capital" bringing insufficient investment demand; "money flow preference" causing insufficient investment demand. He also believes that "involuntary unemployment" can be reduced by stimulating consumption, expanding effective demand, and encouraging investment [2]. Therefore, to achieve full employment, we must abandon the policy of laissez-faire and rely on state intervention. The state uses fiscal and monetary policies to increase government spending, build public projects, print money, expand credit, reduce interest rates, etc., to stimulate investment and increase consumption propensity of the whole society, expand social effective demand, and thus enlarging employment.

\section{Coexistence of unemployment and vacancy}

At the end of the 1950s, the economies of major Western capitalist countries successively fell into the predicament of "stagflation". Keynes's theory of unemployment had failed, and some economists interpreted unemployment from a structural perspective. Tobin is one of them. From the perspective of the incompleteness of the labor market, he believes that labor markets are mostly the industrial, regional local market. Without a unified one, many "barriers" has led to a certain degree of unemployment since the differences in 
labors that are hard to be replaced[3]. Due to changes in the economic structure, the structural unemployment caused by uncoordinated supply and demand of the labor force in occupations, skills, industry, and regional distribution will inevitably lead to the coexistence of unemployment and job vacancies that is converted into the coexistence of unemployment and money wages because of the prices and wages rigidity, causing complications of stagflation. Tobin attributed the complications to the incompleteness of micro market and changes of structure. According to Tobin, it is not enough to solve the problem of unemployment by relying solely on macro fiscal and monetary policies. Instead, we need to wield the labor market and manpower policies to achieve full employment, such as retraining the labor force, developing employment agencies, providing labor market information, solving the conflict between unemployment and job vacancies, and reducing structural unemployment.

\section{Dual Structure Unemployment Theory of Development Economics}

It is not until the 1950s that the employment issue in developing countries caught the attention of Western economists, among which were Lewis, Fei Jinghan, and Todaro. They discussed mainly the employment in the dual economic structure development model. In accordance with the large agricultural population and abundant surplus labor force in developing countries, and Lewis proposed to tackle unemployment through industrialization. Todaro revised "Economic Development in the Third World" and argued that the transfer of rural labor to cities depends on the probability of obtaining high income in the cities and the possibility of becoming unemployed in the long term. He further stated that the characteristics of the dual economic structure of developing countries led to the gap between urban and rural incomes. The following influx of rural residents into the cities has led to serious imbalances in the urban labor market and worsened the unemployment situation. Therefore, Todaro believes that the solution to the problem of rural surplus labor can be viewed from the perspective of agriculture that is by increasing labor productivity in rural areas, increasing the demand for labor in the agricultural sector, and expanding rural employment opportunities. Government should increase investment in construction in rural areas, and pay attention to the development of agriculture and rural areas. And they provide education and quality services, water, electricity, transportation and sanitation facilities for rural residents, improve their living conditions, and narrow the gap between urban and rural areas. Ensuring the economic balance in various regions is the fundamental solution to the problems of employment in developing countries.

\section{THE CAUSE OF THE DIFFICULTY IN THE EMPLOYMENT OF CHINESE COLLEGE STUDENTS}

In the era of "popular education" and the "two-way choice and self-selected career” employment system, undergraduates have obtained the freedom to choose jobs, whereas lost job security, facing high risks in human capital investment. Entering industries that are not match with their majors means that professional knowledge cannot be fully utilized, while working in a low-wage industry means that the return from human capital investment has been taken away. Zheng Gongcheng believes that the "planning system and supplyoriented education mechanism" hampers the employment of graduates. Under the circumstances of enrollment expansion, colleges and universities have not effectively adjusted the education system, professional structure and emphasized ability training. The setting of professional courses in universities is unreasonable, and there are structural contradictions with social demands [6]. While the long-term professional has reduced its social needs, major setup and the scale of enrollment have remained the same. It is difficult to remove or adjust an old professional in real operations. In addition, there are also some problems like the focuses of disciplines in urgent need are not prominent, some colleges and universities are blind to new professionals, and the quality of graduates cultivated is low. From the school's employment guidance for college graduates, if the school is compared to a factory, graduates as the "educational products" produced by colleges and universities, their employment is equivalent to the product sales process, but this product is different from the general one. The quality and sales of products not only affect the reputation and development of the school, but also affect the overall quality and stability of the society [7]. Therefore, schools should attach great importance to the employment of graduates and strengthen the employment guidance for graduates. However, at the current stage, China's employment guidance is generally at a low level, centering on "sending out" and with weak institutions. College students are neither aware of nor satisfied with that.

\section{THE ENLIGHTENMENT OF THE WESTERN UNEMPLOYMENT THEORY TO THE EMPLOYMENT OF UNIVERSITY STUDENTS IN CHINA}

\section{A. Reasonable setting of major and courses}

At present, college students enter the job market, achieving the marketization of employment. However, they are still exposed to the traditional exam-oriented education. What's more, students' social adaptability is generally weak. Compared with Europe and the United States, China does poorer in workstudy combination, so occurs what we call structural unemployment that some students complained that they can not find a job, at the same time some companies do not recruit people, that is unemployment and vacancy coexisting. To solve this problem, professional settings and curriculum settings should be based on a relatively stable long-term social needs and scientific predictions of market needs for majors. Colleges and universities should keep track of job market trends, and make reasonable adjustments according to the needs of all walks of life in society and improve the match between students and social needs [8].

\section{B. Increase rural investment and narrow the gap between urban and rural areas}

The structural unemployment problem of our country's undergraduates is not only reflected in the mismatch between supply and demand, but also in the different employment pressures brought about by differences in regional economic 
development. China is a country with a typical dualistic economy. Household registration management that classifies people according to agricultural and non-agricultural accounts has divided the labor market into two parts: urban and rural areas. For a long time, higher education in our country has been playing the role of identity transformation which is also an important reason why people are expected to obtain it. [9]. From the phenomenon that college students prefer large cities and famous enterprises, it can be said that after investing in human capital, university students, naturally, want to get a better return. However, the current economic and social development in various parts of China is quite different. The working conditions, welfare and security in large cities are better than those in the grass-roots with low wages, which makes it become increasingly difficult to find employment in large and medium-sized cities. Even though, there are still a large number of graduates flocking in each year. Meanwhile, the grassroots, especially those in the western region, are eager for college students and talents who have a strong academic background but few people care. Although the government has also taken measures to narrow the regional gap and urban-rural gap, and ease the household registration system, it is still important to increase the investment in rural areas, increase the productivity of agriculture, and improve the infrastructure in rural areas to narrow the gap between urban and rural areas [10].

\section{Attaching importance to the role of government in employment}

Difficulties in the employment of college students are reflected in the decrease in the salary of people and the increase in the unemployment rate. This is also a major issue in the return on educational investment and the optimal allocation of resources. This requires the government to play its due role in the employment of college students. As a relatively highquality population, college students have a high accumulation of human capital and play an important role in promoting China's economic development. As a typical market full of asymmetric information, the labor market needs to match between supply and demand through accurate and effective channels. The government can maximize the efficiency and quality of graduate employment by providing useful employment information, introducing targeted measures, enhancing macro-control, and improving the employment guidance system.

\section{The importance of human capital investment}

The current difficulty of employment for college students poses a challenge to the early theory of human capital. Although India and the United States faced the problem of employment for university graduates in the 60's and 70's of the 20th century, they eventually managed to transform this temporary talent pressure into the driving force of scientific and technological progress and industrial innovation. This is the important reason why in the era of the Internet economy. India has become Software power and the United States the leader Internet economy. The current difficulty in employment is aligned with China's economic development phase. As the result of the current relatively low level of economic development in China and the expansion of colleges and universities, higher education has transformed prematurely from "elite education" to "popular education". With the development of economy, the employment problem of university graduates will be solved effectively. At present, our country's higher education is still lagging behind in terms of quality. Therefore, it is our priority to pay attention to the reserve of talents, strengthen the awareness of entrepreneurship and innovation, increase the support of fiscal and financial policies for higher education, and firmly establish the concept that talent is the first resource and reinvigorating China with talent.

\section{CONCLUSION}

It is hoped that with the supporting materials in this paper, students can apply suitable professional courses according to reasonable time arrangements during their college life, and make different types of career planning in different grades. We will respond actively to the Party Central Committee's call to alleviate poverty targeted by making the rural investment the key task, while intensifying the government's macro-control to link the employment of students with local employment. We will set up an employment consulting office, in order to increase steadily the employment rate by assorting positions and majors properly, and planning scientifically employment positions.

\section{REFERENCES}

[1] Davis SJ, Haltiwanger J. 1992. Gross job creation, Gross job destruction, and employ ment reallocation. Quarterly Journal of Economics, 107:819864.

[2] KinsI, WellingL. 1995. Search, unemployment, and growth. Journal of Monetary Economics, 35:499-507.

[3] Lane T D. 1994. Wage controls and employment in economics in transition. Journal of Comparative Economics, 19:174- 187.

[4] Zhang Li, Lv Kangyin. Discussion on Employment in China under the Background of Financial Crisis[J] Economic Review, 2009(3). (In Chinese)

[5] Yao Yuqun, Peng Enzhou. Summary of the Discussion on the Difficulties of College Graduates in Employment [J]. Population \& Economics, 2008(3). (In Chinese)

[6] Yuan Zhigang. Economics of Unemployment[M]. Shanghai: Shanghai Joint Publishing Corporation, 1997. (In Chinese)

[7] Chen Ruilin. Research on Employment Difficulty of University Graduates in China[J]. Inquiry into Economic Issues, 2009(3). (In Chinese)

[8] Li Yining, Wu Shitai. Evolution of Western Employment Theory[M]. Huaxia Publishing House. 1988. (In Chinese)

[9] Lai Shengde, Li Chang'an. Major Contradiction and its Countermeasures in the Current Employment Field in China [J]. Economics Information, 2010(3). (In Chinese)

[10] Wang Jifu, Luo Lien. Western Employ ment Theory and Practice and Its En lightenment to China[J]. Journal of Xi'an Jiaotong University(Social Sciences), 2000(12). (In Chinese) 